\title{
ANALISIS PERILAKU AMAN PADA PEKERJA KONSTRUKSI DENGAN PENDEKATAN BEHAVIOR-BASED SAFETY (STUDI DI WORKSHOP PT. X JAWA BARAT)
}

\author{
Fransisca Anggiyostiana Sirait dan Indriati Paskarini \\ Departemen Keselamatan dan Kesehatan Kerja \\ Fakultas Kesehatan Masyarakat Universitas Airlangga \\ E-mail: fransiscaanggi@gmail.com
}

\begin{abstract}
PT. X is a company in steel structure construction and fabricator pole field. In the company's Workshop, there are bending, shearing, and cutting processes. The basic causation of work accident are unsafe behavior and unsafe condition. This research aims to analyze the safe behavior of construction workers with Behavior-Based Safety approach in the stage of define and observe of The DO IT Process, with the ABC (Activator, Behavior, and Consequence) model. This is an observational descriptive research with the cross-sectional design. The respondents of this research are 30 construction workers in Workshop of PT. X. The results of this research showed that all workers have good awareness; 93,3\% of construction workers have good knowledge; 93,1\% have good perception; 92,7\% have good motivation; 93,3\% stated that the safety needs had been fulfilled; 93,3\% of construction workers stated that the existing safety rules of the company had been implemented; $90 \%$ of construction workers ever got positive reinforcement; 85,7\% of construction workers ever got punishment; the construction workers stated that safety training and management role of the company had been implemented. The result also showed the construction workers largely did safety behavior at work. In order to improve safe behavior, the company needs to give training to all construction workers, implement SOP consistently, evaluate and monitor the worker's behavior, and implement the Behavior-Based Safety program (The DO IT Process).
\end{abstract}

Keywords: safe behavior, behavior-based safety, construction company

\begin{abstract}
ABSTRAK
PT. X adalah sebuah perusahaan yang bergerak di bidang konstruksi struktur baja dan tiang fabricator. Dalam Workshop perusahaan tersebut terdapat proses bending, shearing, dan cutting. Penyebab dasar kecelakaan kerja adalah perilaku tidak aman dan kondisi tidak aman. Penelitian ini dilakukan untuk menganalisis perilaku aman pada pekerja konstruksi dengan pendekatan Behavior-Based Safety pada tahapan define dan observe dalam The DO IT Process dengan model ABC (Activator, Behavior, dan Consequence). Penelitian ini merupakan jenis penelitian observasional dengan rancangan cross-sectional. Responden dalam penelitian ini adalah 30 pekerja konstruksi di Workshop PT. X. Hasil penelitian ini menunjukkan bahwa seluruh pekerja konstruksi memiliki kesadaran baik; 93,3\% pekerja konstruksi memiliki pengetahuan baik; 93,1\% pekerja konstruksi memiliki persepsi baik; 92,7\% pekerja memiliki motivasi baik; 93,3\% pekerja konstruksi menyatakan bahwa kebutuhan selamat telah terpenuhi; 93,3\% pekerja konstruksi menyatakan bahwa peraturan K3 berlaku di perusahaan; 90\% pekerja konstruksi menyatakan bahwa pernah mendapatkan positive reinforcement; $85,7 \%$ pekerja konstruksi menyatakan bahwa pernah mendapatkan hukuman; pekerja konstruksi menyatakan bahwa terdapat pelatihan K3 dan peran manajemen yang berlaku di perusahaan. Hasil penelitian juga menunjukkan bahwa sebagian besar pekerja konstruksi telah berperilaku aman dalam bekerja. Untuk meningkatkan perilaku aman, perusahaan perlu memberikan pelatihan untuk seluruh pekerja konstruksi, penerapan SOP secara konsisten, evaluasi dan monitoring perilaku pekerja konstruksi, dan penerapan program Behavior-Based Safety (The DO IT Process).
\end{abstract}

Kata kunci: perilaku aman, behavior-based safety, perusahaan konstruksi

\section{PENDAHULUAN}

Persoalan yang muncul di era industrialisasi adalah kebutuhan pekerja dan peningkatan produktivitas untuk dapat menghasilkan produk yang berkualitas. Kondisi kesehatan dan tersedianya perlindungan keselamatan pekerja akan dapat mempengaruhi produktivitas kerja. Angka kejadian kecelakaan kerja dengan berbagai ancaman di bidang Keselamatan dan Kesehatan Kerja di Indonesia masih cukup tinggi. Kecelakaan kerja masih sering terjadi dalam proses produksi, terutama di sektor jasa konstruksi. Berdasarkan laporan hasil penelitian International Labour Organization (ILO) (1989), hampir setiap hari terjadi kecelakaan kerja yang 
mengakibatkan korban fatal (meninggal), yaitu sekitar 6.000 kasus.

Menurut data Jamsostek, jumlah kecelakaan kerja pada tahun 2007 adalah 65.474 kasus dengan 1.451 orang meninggal, 5.326 orang cacat tetap, dan 58.697 orang cedera. Sedangkan pada tahun 2008 terdapat 94.736 kasus, tahun 2009 terdapat 96.314 kasus, tahun 2010 terdapat 98.711 kasus, tahun 2011 terdapat 99.491 kasus dengan rata-rata 414 kasus per hari, tahun 2012 terdapat 103.074 kasus, dan tahun 2013 terdapat 103.285 kasus kecelakaan kerja.

Berdasarkan riset yang dilakukan oleh National Safety Council (NSC) pada tahun 2011menyebutkan hasil bahwa penyebab kecelakaan kerja adalah $88 \%$ karena perilaku tidak aman (unsafe behavior), 10\% karena kondisi yang tidak aman (unsafe condition), dan 2\% tidak diketahui penyebabnya. Cooper (2001) juga menyatakan bahwa sebagian besar penyebab kecelakaan kerja adalah karena perilaku tidak aman (unsafe behavior) dengan persentasi sebesar 80-95\%. Perilaku tidak aman terjadi karena persepsi dan keyakinan pekerja bahwa mereka merasa ahli di bidangnya dan merasa belum pernah mengalami kecelakaan kerja sehingga kurang ada kepedulian untuk bekerja dengan baik dan benar.

Berikut ini adalah data hasil penggunaan beberapa pendekatan sebagai Safety Intervention Strategies yang telah dilakukan dalam beberapa penelitian dan subjek terkait menurut National Safety Council (NSC).

Tabel 1. Data Hasil Safety Intervention Strategies (By NSC)

\begin{tabular}{lccc}
\hline \multicolumn{1}{c}{ Approach } & Studies & Subject & Reduction (\%) \\
\hline Behavior Based & 7 & 2.444 & 59,6 \\
Ergonomics & 3 & $\mathrm{n} / \mathrm{a}$ & 51,6 \\
Engineering & 4 & $\mathrm{n} / \mathrm{a}$ & 29 \\
Change & & & \\
Problem Solving & 1 & 76 & 20 \\
Gov't Action & 2 & 2 & 18,3 \\
Mgt Audits & 4 & $\mathrm{n} / \mathrm{a}$ & 17 \\
Stress & 2 & 1.300 & 15 \\
Management & & & \\
$\begin{array}{l}\text { Poster Campaign } \\
\text { Personnel }\end{array}$ & 2 & 6.100 & 14 \\
Selection & 26 & 19.177 & 3,7 \\
Near-miss & 2 & $\mathrm{n} / \mathrm{a}$ & 0 \\
Reports & & & \\
\hline
\end{tabular}

Berdasarkan Data Hasil Safety Intervention Strategies (By NSC) pada tabel 1 tersebut dapat diketahui bahwa dengan menggunakan pendekatan
Behavior-Based Safety dalam Safety Intervention Strategies telah menunjukkan hasil keberhasilan pada peringkat pertama dan berarti bahwa mencapai pengurangan tertinggi, yaitu dengan persentase sebesar $59,6 \%$ yang dilakukan pada 7 penelitian dan 2.444 subjek. Hal ini berarti bahwa penggunaan pendekatan Behavior-Based Safety sebagai strategi dalam intervensi lebih efektif untuk digunakan dari pada apabila dibandingkan dengan pendekatanpendekatan yang lainnya, contohnya ergonomics, engineering change, problem solving, dan lainnya.

Teori menurut Cooper (2009), menyebutkan bahwa Behavior-Based Safety merupakan sebuah proses yang menciptakan kemitraan keamanan yang dilakukan antara manajemen dan pekerja dengan fokus yang berkelanjutan terhadap perhatian dan tindakan terhadap setiap orang dan orang lain, serta upaya untuk berperilaku selamat. Salah satu cara untuk mengidentifikasi unsafe condition dan unsafe behavior yaitu dengan melakukan pendekatan perilaku atau yang disebut dengan BBS (BehaviorBased Safety).

Menurut Geller (2001), perilaku aman dapat dilihat dari perilaku pekerja ketika melakukan pekerjaannya di tempat kerja. Pendekatan BBS akan lebih berhasil jika didukung dengan pendekatan dan metode yang mendorong peningkatan perubahan perilaku dari yang tidak aman menjadi perilaku aman guna mencegah terjadinya kecelakaan kerja. Model ABC yang terdiri dari Activator-BehaviorConsequence menjelaskan bahwa perilaku dipengaruhi langsung oleh adanya faktor activator yang mendahului terjadinya perilaku tertentu dan faktor consequence yang akan dapat menentukan perilaku tertentu dilakukan ulang sebagai perilaku baru. Consequence dapat bertindak sebagai activator baru atau activator ke dua yang dapat memicu munculnya perilaku baru atau perilaku lain.

PT. X merupakan sebuah perusahaan yang bergerak di bidang konstruksi struktur baja dan tiang fabricator. PT. X tersebut didirikan sejak tahun 1999. PT. X sebagai produsen tiang baja yang melingkupi sarana infrastruktur dan beberapa bidang strategis di Indonesia, seperti transmisi tiang listrik, transmisi tiang telepon, tiang penerangan, tiang lampu taman atau dekoratif dan tiang-tiang telekomunikasi atau pemancar. Workshop adalah sebuah area kerja yang digunakan untuk melakukan proses produksi material, yaitu diantaranya meliputi proses bending, shearing, dan cutting. Perusahaan tersebut menghasilkan jenis baja struktur fabrikasi, 
contohnya struktur bangunan, jembatan, tank, menara baja, dan struktur peralatan mekanik.

Peneliti telah melakukan studi pendahuluan, yaitu dengan mengobservasi pada beberapa pekerja konstruksi yang terdapat di Workshop PT. X untuk dapat melihat secara langsung perilaku aman pada pekerja konstruksi di perusahaan tersebut. Hasil dari observasi pendahuluan yang telah dilakukan adalah masih ditemukan adanya pekerja konstruksi yang berperilaku kurang aman di perusahaan, misalnya adalah kurang tepat dalam penggunaan APD (Alat Pelindung Diri), berjalan tidak di jalur yang seharusnya, dan mengabaikan adanya rambu-rambu K3 yang terdapat di area kerja. Perilaku kurang aman tersebut dapat meningkatkan risiko terjadinya kecelakaan kerja yang terjadi di tempat kerja. Hal ini berarti bahwa diperlukan penelitian untuk menganalisis perilaku aman pada pekerja di Workshop PT. X sebagai salah satu upaya pencegahan kecelakaan kerja dan untuk meningkatkan keselamatan kerja.

Penelitian ini bertujuan untuk menganalisis perilaku aman pada pekerja konstruksi dengan pendekatan Behavior-Based Safety berdasarkan model ABC (activator, behavior, dan consequence) di Workshop PT. X, Jawa Barat.

Manfaat penelitian bagi perusahaan adalah memberikan gambaran mengenai hasil analisa perilaku aman pada pekerja konstruksi dengan berdasarkan pendekatan Behavior Based Safety di perusahaan, serta dapat menjadi bahan pertimbangan dan saran terkait pelaksanaan program $\mathrm{K} 3$ yang tepat berhubungan dengan implementasi program Behavior-Based Safety. Manfaat penelitian bagi peneliti yang lainnya adalah dapat menjadi bahan pertimbangan dan acuan untuk melakukan penelitian berikutnya. Manfaat penelitian yang lainnya adalah meningkatkan pengetahuan mengenai BehaviorBased Safety sebagai salah satu pendekatan yang digunakan untuk menganalisis perilaku aman pada pekerja konstruksi, meningkatkan pengetahuan dan kemampuan dalam bidang Keselamatan dan Kesehatan Kerja di perusahaan konstruksi, serta dapat meningkatkan kemampuan dalam penelitian dan penulisan karya tulis selanjutnya mengenai Behavior-Based Safety.

\section{METODE}

Penelitian ini merupakan penelitian observasional karena penelitian dilakukan dengan mengamati keadaan dan variabel yang ada di tempat penelitian secara langsung. Penelitian ini menggunakan rancang bangun studi potonglintang (cross -sectional study) dikarenakan peneliti melakukan penelitian dengan pengamatan pada satu kurun waktu atau periode tertentu yaitu ketika melakukan praktik penelitian lapangan.

Penelitian ini dilakukan di Workshop PT. X (Steel Structures and Poles Fabricator), Jawa Barat. Waktu penelitian adalah sejak pembuatan proposal penelitian dan pengumpulan data dilakukan mulai dari bulan Januari sampai Maret 2015.

Populasi penelitian ini adalah seluruh pekerja konstruksi yang meliputi pegawai tetap maupun kontrak di Workshop PT. X Jawa Barat, yaitu sebesar 30 orang. Sampel dalam penelitian ini adalah total populasi penelitian yaitu seluruh pekerja konstruksi di Workshop PT. X, Jawa Barat.

Variabel bebas dalam penelitian ini adalah faktor-faktor yang berperan sebagai activator (pengetahuan tentang faktor bahaya dan perilaku aman, awareness (kesadaran), persepsi tentang bahaya dan risiko kecelakaan kerja, motivasi untuk berperilaku aman, kebutuhan selamat, peran manajemen, peraturan perusahaan tentang K3, dan pelatihan K3) dan faktor-faktor yang berperan sebagai consequence (positive reinforcement dan punishment). Variabel tergantung atau terikat dalam penelitian ini adalah behavior, yaitu perilaku aman pekerja konstruksi.

Teknik pengumpulan dalam penelitian ini adalah bersumber dari data primer meliputi data hasil wawancara langsung, observasi atau pengamatan dengan menggunakan lembar checklist yaitu CBC, pengukuran, dan data sekunder yang berasal dari perusahaan.

Total safe diukur dengan menggunakan rumus Safe Behavior Index menurut Geller (2001) adalah sebagai berikut:

\begin{tabular}{l}
$\begin{array}{l}\text { Safe } \\
\text { behavior }= \\
\begin{array}{l}\text { Index } \\
\text { "Safe" observed }+ \text { "At-risk } \\
\text { (unsafe) }\end{array}\end{array} \times 100 \%$ \\
\hline
\end{tabular}

Persentase Safe Behavior Index yang didapat berdasarkan pada hasil perhitungan dengan rumus tersebut di atas, selanjutnya akan dikategorikan berdasarkan 3 kategori yang meliputi kategori baik, cukup baik, dan kurang baik. Dapat dikatakan "baik" jika persentase Safe Behavior Index $\geq$ $85 \%$; kategori "cukup baik" jika persentase Safe 
Behavior Index menunjukkan hasil antara $60 \%$ sampai dengan $84,9 \%$; dan kategori "kurang baik" jika persentase Safe Behavior Index $\leq 59,9 \%$. Kategori dalam menentukan Safe Behavior Index tidak ditentukan secara jelas oleh Geller (2001), namun hanya terdapat contoh perhitungan yang menjelaskan bahwa hasil perhitungan Safe Behavior Index yang menunjukkan hasil $85 \%$ termasuk ke dalam kategori baik sehingga persentase tersebut kemudian dijadikan sebagai acuan. Kategori hasil perhitungan tersebut juga telah digunakan dalam beberapa penelitian sebelumnya.

Data yang telah terkumpul dari hasil penelitian, kemudian akan diolah secara manual dengan mengecek kelengkapan identitas masing-masing pekerja konstruksi yang menjadi responden, serta akan dilakukan pemeriksaan instrumen pengisian data yang meliputi tahapan editing, coding, counting, entering, sorting, dan tabulating.

Data hasil penelitian yang diperoleh melalui kuesioner, kartu observasi Critical Behavior Checklist (CBC), data sekunder, dan hasil wawancara kemudian disajikan dalam bentuk teks dan tabel. Langkah selanjutnya adalah data tersebut dianalisis dan disajikan dengan penjelasan dari data hasil penelitian yang dideskripsikan dan dirangkum dengan berbagai variabel yang telah diidentifikasi sebelumnya. Hasil analisis yang telah dilakukan dan didapatkan, kemudian akan dihubungkan dengan teori yang ada untuk diambil kesimpulan dari penelitian tersebut.

\section{HASIL}

\section{Gambaran Umum Perusahaan}

PT. X adalah sebuah perusahaan General Supplier, Electrical, and Mechanical Contractor yang berada di Jawa Barat. PT. X mempunyai tujuan jangka panjang sebagai produsen tiang baja yang terkemuka dengan fokus kepuasan pelanggan sehingga secara terus menerus meningkatkan mutu dan pelayanan yang prima. Pimpinan dan seluruh karyawan PT. X berkomitmen untuk melaksanakan sistem Jaminan Mutu ISO 9001:2008 dan programprogram dalam bidang K3 secara konsisten. Departemen K3 secara rutin dan berkala membuat jadwal pemeriksaan kondisi peralatan, observasi proses pekerjaan di area kerja, dan melakukan perbaikan-perbaikan apabila ditemukan kondisi yang kurang tepat atau kurang layak. Evaluasi dan monitoring dilakukan berdasarkan SOP yang ada dan sertifikat yang dimiliki untuk dapat mencapai tujuan dan keberhasilan dalam bidang K3 perusahaan yaitu mengutamakan keselamatan dan kesehatan kerja bagi seluruh pekerja konstruksi di perusahaan tersebut. Untuk mendapatkan hasil produksi yang baik, manajemen PT. X menyadari bahwa dengan fasilitas yang bagus saja tidak cukup, tetapi harus diimbangi dengan sumber daya manusia yang baik pula dan sistem yang diterapkan yang berorientasi pada mutu. ISO 9001:2008 adalah sistem mutu yang telah diterapkan oleh banyak perusahaan di seluruh dunia dan diakui sebagai sistem yang dapat membantu meningkatkan efisiensi dan efektivitas produksi.

Proses produksi di PT. X terdiri dari beberapa tahapan, diantaranya tahapan awal (tahapan menggambarkan desain yang sesuai dengan keinginan pelanggan berkaitan dengan pemesanan), proses penggambaran secara detail atau biasanya disebut dengan single part), proses pengambilan material yang diperlukan untuk dikirim ke Workshop, tahap finishing awal (material masih dalam bentuk besi baja hitam), proses pengiriman ke perusahaan yang bekerja sama dengan PT. X, yaitu perusahaan yang khusus melakukan pengerjaan galvanis atau metode pencegahan karat pada logam atau besi dengan bahan yang lebih tahan terhadap karat, dilakukan setelah barang sudah jadi), dan tahapan akhir (pengiriman pesanan kepada pelanggan).

\section{Karakteristik Pekerja}

Karakteristik pekerja konstruksi yang menjadi responden dalam penelitian ini meliputi usia, jenis kelamin, dan tingkat pendidikan. Usia adalah waktu lama hidup atau adanya seseorang sejak dilahirkan yang dihitung dalam satuan tahun. Distribusi usia pekerja konstruksi di Workshop PT. X Jawa Barat tahun 2015 menunjukkan hasil bahwa sebagian besar pekerja konstruksi $(76,7 \%)$ adalah merupakan kategori usia $21-30$ tahun, sedangkan $13,3 \%$ usia 31-40 tahun, 6,7\% usia lebih dari 40 tahun, dan sisanya sebesar 3,3\% adalah kategori kurang dari 20 tahun. Jenis kelamin meliputi laki-laki dan perempuan. Seluruh responden dalam penelitian ini adalah pekerja konstruksi laki-laki yang bekerja di Workshop PT. X Jawa Barat. Tingkat pendidikan adalah pendidikan formal terakhir yang ditempuh dan ditamatkan oleh seseorang dalam hidupnya. Distribusi tingkat pendidikan pekerja konstruksi di Workshop PT. X Jawa Barat tahun 2015 menunjukkan hasil bahwa sebagian besar pekerja konstruksi (50\%) adalah berstatus tingkat pendidikan terakhir SMU atau SMK, sedangkan 46,7\% adalah 
tingkat SMP dan 3,3\% sisanya adalah tingkat SD. Tingkat pendidikan pekerja yang bervariasi dapat mempengaruhi perilaku dalam bekerja.

\section{Faktor-faktor yang Berperan sebagai Activator}

Activator dapat mendasari setiap perilaku dan menjadi "trigger" dalam melakukan sesuatu, akan tetapi terkadang juga dapat menyebabkan seseorang tidak melakukan sesuatu tersebut lagi.

Tingkat pengetahuan mengenai keselamatan kerja dan perilaku aman dalam bekerja diantaranya adalah tentang beberapa hal yang berkaitan dengan cara menciptakan kondisi selamat, misalnya dengan berperilaku aman dan kondisi aman pada lingkungan sekitar. Berdasarkan distribusi tingkat pengetahuan pekerja dalam penelitian di Workshop PT. X Jawa Barat tahun 2015, terdapat hasil bahwa seluruh pekerja konstruksi yang menjadi responden (100\%) memiliki tingkat pengetahuan yang baik mengenai keselamatan kerja dan perilaku aman ketika bekerja.

Kesadaran merupakan suatu keadaan seseorang yang menunjukkan bahwa ia tahu atau mengerti dengan jelas mengenai apa yang ada dalam pikirannya sehingga selanjutnya mampu untuk mengungkapkan dan akan mengekspresikan hasil yang didapatkan dari stimulus awal. Kesadaran dapat dikategorikan menjadi dua, yaitu baik dan kurang baik. Hasil dari distribusi kesadaran untuk berperilaku aman dalam bekerja pada pekerja konstruksi di Workshop PT. X Jawa Barat tahun 2015 menunjukkan bahwa 50\% dari total pekerja konstruksi yang menjadi responden di Workshop PT. X Jawa Barat memiliki kesadaran yang baik untuk berperilaku aman dalam bekerja dan $50 \%$ pekerja yang lainnya memiliki kesadaran yang kurang baik.

Persepsi adalah suatu pengalaman seseorang mengenai objek atau peristiwa yang diketahui secara langsung dengan menggunakan panca indera. Berdasarkan hasil distribusi persepsi pekerja konstruksi tentang bahaya dan risiko kecelakaan, dapat diketahui bahwa sebagian besar pekerja konstruksi $(96,7 \%)$ memiliki persepsi yang baik, sedangkan sisanya sebesar 3,3\% pekerja konstruksi memiliki persepsi kurang baik.

Motivasi yaitu suatu perangsang keinginan dan daya penggerak kemauan yang pada akhirnya akan dapat membuat seseorang melakukan suatu tindakan atau perilaku. Ada tidaknya motivasi akan dapat menjadi dasar alasan seseorang melakukan suatu perilaku. Hasil distribusi motivasi pekerja konstruksi untuk berperilaku aman dalam bekerja menunjukkan bahwa sebagian besar pekerja konstruksi $(80 \%)$ memiliki motivasi yang baik, sedangkan sisanya sebesar 20\% pekerja konstruksi memiliki motivasi yang kurang baik untuk berperilaku aman dalam bekerja.

Kebutuhan selamat merupakan salah satu dari kebutuhan dasar manusia, yang meliputi rasa ingin dilindungi dan merasa aman serta nyaman ketika berada di tempat kerja. Berdasarkan hasil distribusi kebutuhan selamat pada pekerja konstruksi di PT. X Jawa Barat tahun 2015, dapat diketahui bahwa seluruh pekerja konstruksi yang menjadi responden (100\%) menyatakan bahwa telah terpenuhi kebutuhan selamanya. Kebutuhan selamat tersebut diantaranya adalah adanya jaminan keselamatan, tempat kerja yang aman dan nyaman dengan kondisi lingkungan yang mendukung, ketersediaan alat pelindung diri sesuai dengan kebutuhan, adanya waktu kerja, istirahat yang cukup, dan lainnya.

Berdasarkan hasil wawancara kepada pihak manajemen di PT. X tahun 2015 dapat diketahui bahwa terdapat peran manajemen yang sudah berjalan dengan baik serta terdapat sistem manajemen, tim program, komunikasi dan sumber daya manusia serta peralatan yang termasuk ke dalam infrastruktur peran manajemen. Ada beberapa tim program di PT. X Jawa Barat, yaitu program dalam setiap kegiatan rutin K3 di perusahaan meliputi adanya briefing pagi yang dilakukan rutin setiap hari dengan membahas mengenai target pencapaian selanjutnya. Beberapa sertifikat yang dimiliki oleh PT. X diantaranya yaitu OHSAS 18001:2007, ISO 9001:2008, ISO 140001:2004, dan CHESM (Contractor Health, Environment and Safety Management). Hasil wawancara dengan pihak HSE (manager) dan data sekunder yang diperoleh menunjukkan bahwa terdapat beberapa program dan kegiatan di PT. X sebagai peran manajemen yang dinilai ada dan berperan di perusahaan, yaitu meliputi adanya jadwal pelatihan; evaluasi pelatihan; laporan harian; rapat K3; laporan kecelakaan, insiden, dan PAK (Penyakit Akibat Kerja); laporan pelanggaran APD (Alat Pelindung Diri); laporan daftar ketersediaan APD; Laporan Ketidaksesuaian dan Tindak Lanjut; dan kartu pelanggaran.

Beberapa yang termasuk dalam peraturan perusahaan tentang $\mathrm{K} 3$ adalah adanya prosedur kerja, rambu-rambu mengenai cara bekerja yang baik dan benar, informasi tentang bahaya kecelakaan kerja, dan yang lainnya. Peraturan perusahaan berlaku sebagai pedoman dan acuan dalam bekerja 
sesuai dengan cara yang benar. Peraturan perusahaan mengandung prinsip penerapan yang tegas dan jika ada yang melanggar maka akan diberikan sanksi atau hukuman. Distribusi peraturan perusahaan tentang K3 pada pekerja konstruksi di PT. X menunjukkan hasil bahwa seluruh pekerja konstruksi yang menjadi responden $(100 \%)$ menyatakan bahwa ada peraturan mengenai $\mathrm{K} 3$ yang berlaku di perusahaan tersebut.

Berdasarkan hasil wawancara dengan tim program pelatihan dari departemen training, dapat diketahui bahwa di PT. X Jawa Barat terdapat pelatihan $\mathrm{K} 3$ tahap awal yang disebut dengan basic safety training yang membahas mengenai dasardasar K3, dan selanjutnya ada pelatihan mengenai bekerja pada ketinggian menggunakan body harness, serta pelatihan yang lainnya.

\section{Faktor-faktor yang Berperan sebagai Consequence}

Consequence merupakan hasil atau keluaran dari perilaku seseorang yang dapat menyebabkan perilaku tersebut terulang kembali atau tidak. Faktorfaktor yang berperan sebagai consequence adalah positive reinforcement dan punishment.

Positive reinforcement akan dapat membentuk perilaku yang lebih baik dari perilaku awal yang sebenarnya diinginkan atau dibutuhkan oleh seseorang. Hasil distribusi positive reinforcement yang pernah didapatkan pekerja konstruksi dalam penelitian ini menunjukkan bahwa sebagian besar pekerja konstruksi $(66,7 \%)$ di Workshop PT. X menyatakan bahwa tidak pernah mendapatkan positive reinforcement selama bekerja, sedangkan $33,3 \%$ pekerja konstruksi yang lain menyatakan bahwa pernah mendapatkan positive reinforcement.

Hukuman atau punishment adalah faktor yang mendukung perilaku aman yang dapat dilakukan ulang untuk menghindari terjadinya perilaku tidak aman. Distribusi hukuman pada pekerja konstruksi di Workshop PT. X menunjukkan hasil bahwa sebagian besar pekerja konstruksi yang menjadi responden $(76,7 \%)$ tidak pernah mendapatkan hukuman selama bekerja di PT. X Jawa Barat, sedangkan 23,3\% pekerja konstruksi lainnya menyatakan bahwa pernah mendapatkan hukuman sebagai akibat dari pelanggaran yang pernah dilakukan misalnya tidak memakai alat pelindung diri berupa seragam dan safety helmet dengan baik dan benar, serta beberapa pelanggaran yang lainnya.

\section{Perilaku Aman (Safe Behavior) Pekerja Konstruksi}

Perilaku aman dapat dipengaruhi oleh beberapa faktor. Perilaku aman pada pekerja konstruksi dapat dilihat dengan cara pengamatan secara langsung mengenai kegiatan yang dikerjakan selama bekerja, cara melakukan pekerjaan dengan benar atau salah, kondisi tempat kerja yang mendukung, dan beberapa hal lainnya. Distribusi perilaku aman pada pekerja konstruksi di Workshop PT. X Jawa Barat 2015 dapat dilihat pada tabel 2 berikut ini:

Tabel 2. Distribusi Perilaku Aman Pekerja Konstruksi di Workshop PT. X Jawa Barat Tahun 2015

\begin{tabular}{lcc}
\hline \multicolumn{1}{c}{ Perilaku Aman } & Frekuensi (n) & Persentase (\%) \\
\hline Baik & 12 & 40 \\
Cukup Baik & 16 & 53,3 \\
Kurang Baik & 2 & 6,7 \\
\hline Jumlah & $\mathbf{3 0}$ & $\mathbf{1 0 0}$ \\
\hline
\end{tabular}

Berdasarkan tabel 2 tersebut, dapat diketahui bahwa sebagian besar pekerja konstruksi yang menjadi responden $(53,3 \%)$ telah berperilaku aman dalam tingkat yang cukup baik selama berstatus pekerja konstruksi di PT. X Jawa Barat.

\section{Distribusi Silang Perilaku Aman Pekerja dengan Faktor-Faktor yang Berperan sebagai Activator}

Perilaku aman pada pekerja dapat didasari oleh faktor yang berperan sebagai activator (trigger atau pemicu), yaitu meliputi pengetahuan, kesadaran, persepsi, motivasi, kebutuhan selamat, peraturan $\mathrm{K} 3$, dan faktor yang lainnya. Distribusi silang antara perilaku aman pekerja dengan beberapa faktor yang berperan sebagai activator dapat dilihat pada tabel 3 . Berdasarkan tabel 3 tersebut, dapat diketahui bahwa sebagian besar pekerja konstruksi yang memiliki pengetahuan baik $(53,3 \%)$ telah berperilaku aman dalam tingkat cukup baik. Sebagian besar pekerja konstruksi yang memiliki kesadaran baik $(53,3 \%)$ telah berperilaku aman dalam tingkat cukup baik, sedangkan sebagian besar pekerja konstruksi yang memiliki kesadaran kurang baik $(53,3 \%)$ juga telah berperilaku aman dalam tingkat cukup baik. Sebagian besar pekerja konstruksi yang memiliki persepsi yang baik $(55,2 \%)$ telah berperilaku aman 
dalam tingkat cukup baik. Sebagian besar pekerja konstruksi yang memiliki motivasi baik $(41,7 \%)$ telah berperilaku aman dalam tingkat cukup baik. Sebagian besar pekerja konstruksi yang menyatakan bahwa kebutuhan selamat selama menjadi pekerja dapat terpenuhi $(53,3 \%)$ juga telah berperilaku aman dalam tingkat cukup baik. Sebagian besar pekerja konstruksi yang menyatakan bahwa terdapat peraturan perusahaan mengenai $\mathrm{K} 3$ dan berlaku di perusahaan $(53,3 \%)$ telah berperilaku aman dalam tingkat cukup baik.

Tabel 3. Distribusi Silang Perilaku Aman Pekerja Konstruksi dengan Faktor-Faktor yang Berperan sebagai Activator di Workshop PT. X Jawa Barat Tahun 2015

\begin{tabular}{|c|c|c|c|c|c|c|c|c|}
\hline \multirow{3}{*}{ Activator } & \multicolumn{6}{|c|}{ Perilaku Aman } & \multirow{2}{*}{\multicolumn{2}{|c|}{ Total }} \\
\hline & \multicolumn{2}{|c|}{ Baik } & \multicolumn{2}{|c|}{$\begin{array}{c}\text { Cukup } \\
\text { Baik }\end{array}$} & \multicolumn{2}{|c|}{$\begin{array}{c}\text { Kurang } \\
\text { Baik }\end{array}$} & & \\
\hline & $\mathbf{n}$ & $\%$ & $\mathbf{n}$ & $\%$ & $\mathbf{n}$ & $\%$ & $\mathbf{n}$ & $\%$ \\
\hline \multicolumn{9}{|c|}{ Pengetahuan } \\
\hline Baik & 12 & 40 & 16 & 53,3 & 2 & 6,7 & 30 & 100 \\
\hline \multicolumn{9}{|l|}{ Kesadaran } \\
\hline Baik & 7 & 46,7 & 8 & 53,3 & 0 & 0 & 15 & 100 \\
\hline Kurang baik & 5 & 33,3 & 8 & 53,3 & 2 & 13,3 & 15 & 100 \\
\hline \multicolumn{9}{|l|}{ Persepsi } \\
\hline Baik & 11 & 37,9 & 16 & 55,2 & 2 & 6,9 & 29 & 100 \\
\hline Kurang baik & 1 & 100 & 0 & 0 & 0 & 0 & 1 & 100 \\
\hline \multicolumn{9}{|l|}{ Motivasi } \\
\hline Baik & 12 & 50 & 10 & 41,7 & 2 & 8,3 & 24 & 100 \\
\hline Kurang baik & 0 & 0 & 6 & 100 & 0 & 0 & 6 & 100 \\
\hline \multicolumn{9}{|c|}{ Kebutuhan Selamat } \\
\hline Terpenuhi & 12 & 40 & 16 & 53,3 & 2 & 6,7 & 30 & 100 \\
\hline \multicolumn{9}{|c|}{ Peraturan K3 } \\
\hline $\begin{array}{l}\text { Ada dan } \\
\text { berlaku }\end{array}$ & 12 & 40 & 16 & 53,3 & 2 & 6,7 & 30 & 100 \\
\hline
\end{tabular}

Tabel 4. Distribusi Silang Perilaku Aman Pekerja Konstruksi dengan Faktor-Faktor yang Berperan sebagai Consequence di Workshop PT. X Jawa Barat Tahun 2015

\begin{tabular}{|c|c|c|c|c|c|c|c|c|}
\hline \multirow{3}{*}{ Consequence } & \multicolumn{6}{|c|}{ Perilaku Aman } & \multirow{2}{*}{\multicolumn{2}{|c|}{ Total }} \\
\hline & \multicolumn{2}{|c|}{ Baik } & \multicolumn{2}{|c|}{$\begin{array}{c}\text { Cukup } \\
\text { Baik }\end{array}$} & \multicolumn{2}{|c|}{$\begin{array}{c}\text { Kurang } \\
\text { Baik }\end{array}$} & & \\
\hline & $\mathrm{n}$ & $\%$ & $\mathrm{n}$ & $\%$ & $\mathrm{n}$ & $\%$ & $\mathrm{n}$ & $\%$ \\
\hline \multicolumn{9}{|c|}{ Positive Reinforcement } \\
\hline Pernah & 6 & 60 & 3 & 30 & 1 & 10 & 10 & 100 \\
\hline Tidak pernah & 6 & 30 & 13 & 65 & 1 & 5 & 20 & 100 \\
\hline \multicolumn{9}{|l|}{ Punishment } \\
\hline Pernah & 4 & 57,1 & 2 & 28,6 & 1 & 14,3 & 7 & 100 \\
\hline Tidak pernah & 8 & 34,8 & 14 & 60,9 & 1 & 4,3 & 23 & 100 \\
\hline
\end{tabular}

\section{Distribusi Silang Perilaku Aman Pekerja dengan Faktor-Faktor yang Berperan sebagai Consequence}

Adanya consequence berkaitan dengan adanya perilaku aman dan perilaku tidak aman yang dilakukan oleh pekerja konstruksi. Positive reinforcement meliputi reward atau hadiah lainnya pernah didapatkan oleh pekerja konstruksi yang telah berperilaku aman, sedangkan punishment atau hukuman akan diberikan kepada pekerja konstruksi yang telah melakukan perilaku tidak aman atau tindak pelanggaran. Consequence dapat menjadi dasar penyebab munculnya perilaku baru sebagai kelanjutan dari adanya perubahan perilaku sebelumnya menjadi perilaku baru yang lebih baik yaitu perilaku aman dalam bekerja. Distribusi silang antara perilaku aman pekerja konstruksi dan faktorfaktor yang berperan sebagai consequence dapat dilihat pada tabel 4 .

Berdasarkan tabel 4 tersebut, dapat diketahui bahwa sebagian besar pekerja konstruksi yang pernah mendapatkan positive reinforcement $(60 \%)$ seperti dalam bentuk pemberian pujian dan promosi kerja, telah berperilaku aman dalam tingkat baik; sedangkan sebagian besar pekerja konstruksi yang menyatakan tidak pernah mendapatkan positive reinforcement (65\%) telah berperilaku aman dalam tingkat cukup baik. Sebagian besar pekerja konstruksi yang menyatakan pernah mendapatkan hukuman di perusahaan $(57,1 \%)$ telah berperilaku aman dalam tingkat baik, sedangkan sebagian besar pekerja konstruksi yang menyatakan bahwa tidak pernah mendapatkan hukuman selama bekerja di perusahaan tersebut $(60,9 \%)$ telah berperilaku aman dalam tingkat cukup baik. Berikut ini adalah tabel 4 yang menunjukkan hasil distribusi silang perilaku aman dan faktor yang berperan sebagai consequence di Workshop PT. X.

\section{PEMBAHASAN}

Activator dapat mendasari setiap perilaku yang dilakukan seseorang sebelum perilaku tersebut terjadi. Menurut Cooper (2001), peran activator dapat menyebabkan perilaku akan dilakukan, tetapi juga dapat menyebabkan perilaku tersebut tidak terjadi. Faktor yang berperan sebagai activator di Workshop PT. X meliputi pengetahuan tentang faktor bahaya dan perilaku aman, awareness (kesadaran), persepsi tentang bahaya dan risiko kecelakaan kerja, motivasi untuk berperilaku aman, kebutuhan 
selamat, peran manajemen, peraturan perusahaan tentang K3, dan pelatihan K3.

Menurut Notoatmodjo (2012), pengetahuan adalah hasil tahu dari seseorang mengenai objek tertentu yang didapatkannya dari indera yang dimiliki. Sesuatu yang dapat dilihat, didengar, dirasakan, dan diungkapkan akan menjadi sebuah pemahaman atau pengetahuan baru. Pengetahuan dapat mempengaruhi cara berpikir dan perilaku seseorang. Dalam penelitian ini diberikan pertanyaan mengenai beberapa hal yang menyangkut pengetahuan pekerja konstruksi yang menjadi responden tentang faktor bahaya dan perilaku aman. Seseorang dapat dikatakan berpengetahuan baik jika mengetahui pernyataan yang benar mengenai faktor bahaya dan perilaku aman. Sebagian besar pekerja konstruksi sebagai responden mengetahui bahwa kecelakaan kerja merupakan keadaan tidak selamat yang disebabkan oleh perilaku tidak aman, misalnya tidak menggunakan APD dan memakai peralatan atau mesin kerja sesuai prosedur yang benar.

Sebagian besar pekerja konstruksi (responden dalam penelitian) mengetahui bahwa di perusahaan terdapat SOP (Standart Operating Procedure) dan peraturan K3 serta menyatakan bahwa sudah berlaku secara konsisten di perusahaan. Pekerja konstruksi yang berpengetahuan baik terkadang belum tentu mau dan mampu untuk berperilaku aman, dapat dikarenakan oleh adanya faktor lain, misalnya kesadaran dan motivasi dari lingkungan sekitar.

Berdasarkan hasil penelitian di Workshop PT. X, dapat diketahui bahwa sebagian dari total pekerja konstruksi yang menjadi responden dalam penelitian memiliki kesadaran yang baik untuk berperilaku aman dalam bekerja, sedangkan sebagian lainnya memiliki kesadaran yang kurang baik. Hal tersebut dapat disebabkan adanya kemauan dan kemampuan dalam berperilaku aman dalam bekerja. Jika pekerja konstruksi memiliki kesadaran yang baik maka dapat terjadi adanya perilaku aman ketika melakukan pekerjaan karena pada dasarnya sudah ada kesadaran yang baik pada diri pekerja sendiri. Secara tidak langsung atau secara tidak sadar, seseorang dapat berperilaku aman karena adanya faktor-faktor lain yang mendasari dan mempengaruhi diri seseorang untuk melakukannya.

Hasil penelitian di Workshop PT. X menunjukkan bahwa sebagian besar pekerja konstruksi memiliki kesadaran yang baik mengenai perilaku aman ketika bekerja. Hal tersebut berarti bahwa pekerja konstruksi memiliki kesadaran, mereka mau dan mampu untuk melakukan perilaku aman ketika bekerja. Faktor lain adalah adanya rasa peduli dari masing-masing individu untuk berani menegur dan mengingatkan sesama pekerja konstruksi satu sama lain ketika melakukan tindakan yang tidak aman dalam bekerja. Pekerja konstruksi dapat dikatakan memiliki kesadaran yang baik apabila tidak merasa terpaksa untuk berperilaku aman dalam bekerja, baik karena ada atau tidaknya sanksi yang berlaku di perusahaan tempat bekerja. Jika seorang pekerja hanya mau menggunakan APD ketika ada inspeksi dari petugas $\mathrm{K} 3$ atau pimpinan dan merasa bahwa pemakaian APD hanya sebagai sebuah kewajiban, maka pekerja tersebut dapat dikatakan belum memiliki kesadaran yang cukup baik.

Teori Health Belief Model menjelaskan bahwa persepsi individu adalah tentang manfaat yang diperoleh dari tindakan yang diambil. Contohnya adalah seseorang yang mungkin akan melakukan tindakan preventif, yaitu dengan mengubah gaya hidup, meningkatkan kepatuhan dan upaya pencegahan yang lainnya. Masing-masing individu berbeda satu sama lain. Namun sebagian besar pekerja konstruksi yang menjadi responden dalam penelitian ini memiliki persepsi yang cukup baik tentang bahaya dan risiko kecelakaan kerja. Persepsi yang baik dalam hal ini diantaranya adalah karena adanya dukungan dari responden mengenai pernyataan bahwa akan terdapat bahaya jika pekerja tidak berperilaku aman. Selain itu adanya pernyataan bahwa pekerjaan akan tetap berlangsung dengan aman meskipun tidak mengikuti peraturan yang berlaku bukan merupakan persepsi yang baik.

Motivasi yang baik dapat ditunjukkan dengan adanya faktor pendorong yang mendukung pekerja berperilaku aman dan bekerja sesuai dengan peraturan atau prosedur. Adanya hadiah (reward) bagi yang diberikan bagi pekerja konstruksi yang telah berperilaku aman dapat menjadi sebuah motivasi yang mendukung dan memberi semangat pekerja untuk terus melakukan perilaku aman dalam bekerja dan akan menjadi motivasi baru bagi pekerja lain untuk ikut serta melakukan perilaku aman. Perhatian dan dukungan secara langsung, baik dari antar pekerja, supervisor, dan pimpinan perusahaan dapat menjadi sebuah motivasi bagi pekerja untuk melakukan pekerjaan yang didasari oleh perilaku aman. Motivasi dapat diberikan untuk mengingatkan pekerja yang melanggar peraturan di perusahaan agar tidak mengulanginya lagi.

Kebutuhan selamat adalah hal yang menyangkut perlindungan bagi diri pekerja konstruksi dari 
bahaya-bahaya yang ada di tempat kerja yang harus dipenuhi oleh perusahaan untuk dapat mewujudkan perilaku aman pekerja, seperti peralatan keselamatan, ketersediaan APD, waktu kerja yang cukup, dan tempat kerja yang aman. Perilaku aman dapat terbentuk jika ada dan terpenuhinya kebutuhan keamanan dan keselamatan kerja. Hasil penelitian menunjukkan bahwa pekerja konstruksi telah mendapatkan jaminan kebutuhan selamat di perusahaan tempat mereka bekerja. Jika pekerja-pekerja tersebut mendapatkan jaminan keselamatan, maka mereka akan merasa aman dan nyaman ketika bekerja, sehingga akan dapat meningkatkan produktivitas kerja. Selain itu juga karena adanya rasa kepercayaan akan keselamatan diri yang didapatkan dari kebutuhan selamat yang telah terpenuhi.

Peran manajemen di PT. X sudah berjalan dengan baik. Hal ini salah satunya didasari oleh adanya sistem manajemen, tim program, komunikasi dan sumber daya manusia serta peralatan yang termasuk ke dalam infrastruktur peran manajemen. Sumber daya manusia disesuaikan dengan pengalokasian peralatan yang digunakan dalam kerja. Ada beberapa tim program di PT. X, diantaranya program dalam setiap kegiatan rutin $\mathrm{K} 3$ di perusahaan. Kegiatan rutin tersebut meliputi cek ketersediaan obat, cek kebersihan toilet, inspeksi kepatuhan pemakaian APD, tim program pelatihan dan pengembangan sumber daya manusia.

Pada dasarnya setiap pelatihan bertujuan untuk menambah pengetahuan dan kemampuan pekerja konstruksi, dalam hal ini pengetahuan mengenai K3 dalam penerapan di tempat kerja. Pada setiap pelaksanaan pelatihan yang terdapat di PT. X Jawa Barat, pekerja akan diberikan kuesioner di akhir pertemuan atau setelah pelatihan dilaksanakan. Hal ini berguna untuk melihat apakah ada manfaat yang didapatkan dari materi pelatihan, meliputi pemahaman materi yang diberikan dan kemampuan untuk mengimplementasikan dalam proses melakukan pekerjaan.

Adanya positive reinforcement yang diberikan kepada pekerja konstruksi dapat mendukung dan menjadi pendorong untuk melakukan perilaku aman dalam bekerja. Salah satu contohnya adalah supervisor dan pimpinan perusahaan memberikan pujian dan penghargaan atau reward kepada pekerja konstruksi yang berperilaku aman, bahkan pemberian kenaikan pangkat dapat memberi semangat pekerja konstruksi untuk mau dan mampu melakukan pekerjaan sesuai dengan SOP yang berlaku. Perilaku baru atau perubahan perilaku menjadi yang lebih baik dan aman yang dilakukan oleh pekerja konstruksi juga dapat didasari dengan adanya faktor sebagai consequence, yaitu berupa positive reinforcement dan punishment yang sudah pernah didapatkan sebelumnya. Pemberian hukuman kepada pekerja yang melanggar peraturan dan berperilaku tidak aman dapat menjadi sesuatu yang ditakuti dan dihindari, misalnya ketika berperilaku tidak aman mendapatkan teguran dari pimpinan perusahaan, sanksi administratif, bahkan pemotongan insentif akibat dari pelanggaran yang dilakukan.

Daftar perilaku yang diamati dalam penelitian ini yang terdapat dalam lembar Critical Behavior Checklist adalah berkaitan tentang Standart Operating Procedure (SOP), Housekeeping (5S), Body Positioning (Ergonomics and Manual handling), Personal Protective Equipment (PPE), Communicating, Workshop, Tools Equipment, Body Protecting and Pacing of Work, dan Driving of work. Beberapa temuan perilaku tidak aman pada pekerja konstruksi di Workshop PT. X adalah tidak menggunakan APD dengan baik dan benar, yaitu tidak konsisten dalam pemakaian seragam dan safety shoes dengan alasan kurang nyaman apabila seragam dan safety shoes selalu digunakan ketika bekerja. Temuan perilaku tidak aman yang lainnya adalah pekerja sedang bergurau ketika melakukan pekerjaan, Hal ini akan berbahaya bagi dirinya sendiri dan orang lain apabila tidak konsentrasi dengan baik dan memperhatikan SOP yang benar dalam bekerja.

Berdasarkan penelitian yang telah dilakukan, menjelaskan bahwa hasilnya sesuai dengan teori yang menyebutkan adanya faktor-faktor yang berperan sebagai activator dan consequence. Faktor yang berperan sebagai activator dapat menjadi pemicu atau perangsang munculnya suatu perilaku dan akan melahirkan atau memunculkan adanya pemberian faktor-faktor yang berperan sebagai consequence yang akan didapatkan sebagai outcome dari perilaku aman yang telah dilakukan tersebut. Jika seseorang berperilaku benar (berperilaku aman) maka akan mendapatkan konsekuensi yang baik atau bermanfaat, namun sebaliknya, jika seseorang berperilaku salah (berperilaku tidak aman) maka akan mendapatkan sanksi atau hukuman sebagai konsekuensi atas kesalahan dan pelanggaran yang telah dilakukannya. 


\section{SIMPULAN}

Berdasarkan hasil penelitian yang dilakukan, didapatkan kesimpulan bahwa activator yang memiliki nilai tertinggi pada pekerja konstruksi di Workshop PT. X Jawa Barat adalah pengetahuan yang baik tentang faktor bahaya dan perilaku aman, kebutuhan selamat yang terpenuhi, peran manajemen dan peraturan mengenai $\mathrm{K} 3$ yang berlaku di perusahaan, serta motivasi yang baik untuk berperilaku aman. Hasil penelitian menunjukkan bahwa perilaku aman pada pekerja konstruksi di Workshop PT. X yang memiliki nilai tertinggi adalah kategori "cukup baik", meliputi penggunaan APD yang benar dan sesuai dengan jenis pekerjaannya serta bekerja dengan berdasarkan SOP yang ada di perusahaan tersebut. Hasil penelitian juga menunjukkan bahwa consequence yang memiliki nilai tertinggi pada pekerja konstruksi di Workshop PT. X adalah punishment atau hukuman yang tidak pernah didapatkan oleh pekerja konstruksi selama bekerja di perusahaan tersebut. Perilaku aman dalam kategori "baik" pada pekerja konstruksi di Workshop PT. X yang memiliki nilai tertinggi adalah didasari oleh adanya motivasi dan kesadaran yang baik untuk berperilaku aman sebagai activator serta positive reinforcement yang pernah didapatkan pekerja konstruksi sebagai consequence.

Saran yang dapat diberikan kepada pihak perusahaan adalah membuat jadwal rutin mengenai pelatihan K3 yang berkaitan dengan proses pekerjaan di Workshop PT. X Jawa Barat, melakukan monitoring dan evaluasi pada capaian program bidang $\mathrm{K} 3$ yang meliputi hasil observasi perilaku pekerja konstruksi dalam bekerja, dan kondisi lingkungan di area kerja. Saran yang dapat diberikan kepada pekerja konstruksi di Workshop PT. X Jawa
Barat adalah meningkatkan kesadaran mengenai pentingnya $\mathrm{K} 3$, menaati setiap peraturan yang berlaku di perusahaan, dan tidak melakukan tindakan pelanggaran. Saran untuk seluruh pihak perusahaan, baik pimpinan maupun pekerja konstruksi adalah konsistensi dalam penerapan aspek-aspek K3 dalam bekerja dan memiliki komitmen yang kuat mengenai penerapan program-program pendekatan Behavior-Based Safety (The DO IT Process dengan menggunakan lembar Critical Behavior Checklist).

\section{DAFTAR PUSTAKA}

Cooper, D. 2001. Improving Safety Culture: A Pratical Guide, Applied Behavioral Sience. UK.

Cooper, D. 2009. Behavioral Safety a Framework for Success. Indiana: BSMS Inc.

Geller, S.E. 2001. The Psychology 07 Safety Handbook. Boca Raton. Lewis Publisher.

Geller, E.S. 2001. Working Safe: How to Help People Actively Care for Health and Safety. 2nd Edition. USA: CRC Press LLC.

International Labour Office (ILO). 1989. Pencegahan Kecelakaan Kerja. Jakarta. PT. Gramedia.

Jamsostek. 2011. Laporan Tahunan Tahun 2010. Disitasi pada: http://www.jamsostek.co.id/ content_file/annual_report_2010.pdf (sitasi tanggal 12 Desember 2014).

Jamsostek. 2014. Laporan Tahunan Tahun 2013. Disitasi pada:http://www.jamsostek.co.id/ content_file/annual_report_2013.pdf (sitasi tanggal 12 Desember 2014).

Notoatmodjo, S. 2012. Pendidikan dan Perilaku Kesehatan. Jakarta: Rineka Cipta.

Sirait, F.A. 2015. Analisis Perilaku Aman pada Tenaga Kerja dengan Pendekatan Behavior-Based Safety. Skripsi. Surabaya: Universitas Airlangga. 